\title{
Central Standard Time
}

National Cancer Institute

\section{Source}

National Cancer Institute. Central Standard Time. NCI Thesaurus. Code C116265.

Local standard time, based at the 90th meridian west of the Greenwich Observatory, established as six hours behind Coordinated Universal T ime. 